\title{
IN VITRO ANTIOXIDANT AND ANTIULCEROGENIC ACTIVITY OF CAYRATIA PEDATA VAR. GLABRA AGAINST EXPERIMENTALLY INDUCED GASTRIC LESIONS IN WISTAR STRAIN ALBINO RATS
}

\author{
KALAICHELVI K, SHARMILA S*, DHIVYA SM \\ PG and Research, Department of Botany, Vellalar College for Women, Thindal, Erode, Tamil Nadu, India. Email: drsharmilas@yahoo.com \\ Received: 15 May 2017, Revised and Accepted: 30 September 2017
}

ABSTRACT

Objective: To quantify the phytochemical constituents, scavenging different free radicals and assess the antiulcer property of aerial plant extracts of Cayratia pedata var. glabra.

Methods: Quantitative analysis was performed to confirm and quantify the presence of phenolics, tannin content and total flavonoids in the aerial plant extracts of the study plant. Reducing power assay, 2, 2- diphenyl-1-picryl-hydrazyl (ABTS), ABTS ${ }^{*+}$ and metal chelating activity were used in this study. To evaluate the anti-ulcerogenic activity of ethanolic extract of $C$. pedata var. glabra, against indomethacin-induced gastric ulcers in rats.

Results: The results of quantification of phytoconstituents showed that the total phenolic and total flavonoid content were maximum in the ethanolic extract. The results of the antioxidant property of $C$. pedata var. glabra showed that all the extracts possess a different range of free radical scavenging activities, which is in dose-dependent manner. The ethanolic extract of the study plant produced gastroprotective effect in indomethacin-induced rats showed the decreased level of ulcer index, gastric volume, free acidity, total acidity, total protein and increased level of percentage of protection, and $\mathrm{pH}$ were calculated from the effective concentrations of plant sample $(400 \mathrm{mg} / \mathrm{kg})$ compared with Omeprazole $(10 \mathrm{mg} / \mathrm{kg})$.

Conclusions: It is concluded that, the $C$. pedata var. glabra contains strong secondary metabolites; natural source of antioxidants and different extracts of this plant possesses good free radical scavenging activity. This present study indicates that ethanolic extract of C. pedata var. glabra has potential antiulcer activity in this tested model. In future, it can be used as a bioactive source of natural antioxidants and are potential natural resources for pharmacology of functional foods.

Keywords: Cayratia pedata var. glabra, Radical scavenging, Antioxidant, Gastroprotective.

(c) 2018 The Authors. Published by Innovare Academic Sciences Pvt Ltd. This is an open access article under the CC BY license (http://creativecommons. org/licenses/by/4. 0/) DOI: http://dx.doi.org/10.22159/ajpcr.2018.v11i1.19986

\section{INTRODUCTION}

Oxidative stress ultimately develops free radicals has been implicated in etiology of a number of human ailments [1,2]. A free radical is a radical containing unpaired electron. Free radicals are highly reactive due to the presence of unpaired electrons. These play a major role in the formation of chronic and degenerative diseases including cancer, autoimmune, inflammatory, cardiovascular, neurodegenerative diseases, and aging $[3,4]$. Recent studies have confirmed that free radicals would injure nearby structures including DNA, proteins, or lipids. Radical scavenging antioxidants are mainly significant in protecting cells from the injury of free radical [5]. Many researchers are now focusing on the deleterious effects of reactive oxygen species (ROS) and the beneficial effects of antioxidants against these effects. Hence, compounds, especially from natural sources capable of protecting against ROS, mediated damage may have potential application in the prevention and/or curing of diseases [6,7].

Variety of bioactive substances present in medicinal plants is widely used against various diseases. The demand for natural food constituents has resulted in broad research on naturally occurring antioxidants which are able to deactivate highly reactive free radicals [8]. Recently, the ability of the phenolic substances including flavonoids, phenolic acids, tannins, and lignins to act as potential antioxidants has been extensively investigated [9]. At present, the synthetic antioxidants might be unsafe, and its toxicity has been criticized. It is generally assumed that frequent use of plant-derived phytochemicals may contribute to shift the stability in the direction of a sufficient antioxidant status. As a result, attention in natural antioxidants, in particular, plant origin, has deeply amplified in recent years [10]. Ulcers are an open sore of the skin or mucus fluid layer portrayed by sloughing of aggravated dead tissue. There are numerous sorts of ulcer, for example, mouth ulcer, throat ulcer, peptic ulcer, and genital ulcer. Of this peptic ulcer is seen among numerous individuals. Gastric ulcers are situated in the stomach, portrayed by agony; ulcers are basic in more seasoned age bunch [11].

Cayratia pedata var. glabra belongs to the family Vitaceae, commonly known as "Kattuppirandai" is one such endemic and endangered species in Thaisholai, Nilgiris South Division, and Western Ghats. With the patronage of veteran ethnic group traditional knowledge of this region, the species $C$. pedata var. glabra was selected for the antioxidant and antiulcer activity. It is a perennial climber grows up to a height of 8-12 m with nodes and internodes having five foliolate leaves with $(2-3 \mathrm{~cm})$ long petioles and elliptic to oblong leaflets. Inflorescence arises just opposite to the leaves on the stem. It is axillary, corymbose cymes and divaricate. Flowers are bisexual, greenish, and fruiting peduncles $(2-5 \mathrm{~cm})$ long. Fruits are slightly green in color, fleshy and bilobed shape at apex. Fruit is the important differentiable characterization among the other genus [12]. In Indian traditional system of medicine, the study genus is used as astringent, diarrhea, refrigerant, hysteria, wound healing, and ulcers [13]. The preliminary phytochemical screening of C. pedata var. glabra revealed the presence of proteins, amino acids, alkaloids, anthraquinones, flavonoids, glycosides, phenols and tannins, steroids and sterols, triterpenoids, and volatile oil [14]. The findings of the current study can be useful to progress and surge further scientific investigation on the aerial parts of this species and also developing a standardized profile of aerial parts of $C$. pedata var. glabra which would be of immense use to assess antiulcer activity of this plant species. 


\section{MATERIALS AND METHODS}

\section{Plant collection and extraction}

Aerial plant of $C$. pedata var. glabra was collected from Thiashola, Manjoor, Nilgiris South Division, and Western Ghats before that we got proper permission from the Principal Chief Conservator of Forests, Chennai, and the District Forest Officer, Ooty under Section 28 (i) of Wildlife Protection Act, 1972, in the month of October, and the voucher herbarium specimen was processed followed by standard methods Jain and Rao [15]. The collected plants were identified with the help of the existing Floras [16-18] and the identity is authenticated with type specimens available in the herbarium of Botanical Survey of India, Southern Circle, TNAU Campus, Coimbatore (No. BSI/SRC/5/23/2010$11 /$ Tech. 1300), Tamil Nadu. Some quantities of leaves and total aerial parts were air dried, powdered and stored in airtight containers. The air-dried, powdered plant material was extracted in Soxhlet apparatus successively with different solvents and the extracts obtained were used for phytochemical quantification and antioxidant studies.

\section{Quantitative phytochemical studies}

Determination of total phenolics and tannins were determined following the procedure of Siddhuraju and Becker [19]. Determination of total flavonoid contents were followed as per the method of Zhishen et al. [20].

\section{Reducing power assay}

The reducing power capacity of the plant was assessed by the modified method of Siddhuraju et al. [21], 20-100 $\mu$ g of extract was taken in $1 \mathrm{ml}$ of phosphate buffer and $5 \mathrm{ml}$ of $0.2 \mathrm{M}$ phosphate buffer (pH 6.6) was added. To this, $5 \mathrm{ml}$ of $1 \%$ potassium ferricyanide solution was added, and the mixture was incubated at $50^{\circ} \mathrm{C}$ for $20 \mathrm{~min}$. After the incubation, $5 \mathrm{ml}$ of $10 \%$ TCA was added. The content was then centrifuged at $1000 \mathrm{rpm}$ for $10 \mathrm{~min}$. The upper layer of the supernatant $(5 \mathrm{ml})$ was mixed with $5 \mathrm{ml}$ of distilled water and $0.5 \mathrm{ml}$ of $0.1 \%$ ferric chloride. The absorbance of the reaction mixture was read spectroscopically at $700 \mathrm{~nm}$.

\section{Free radical scavenging activity on 1,1-diphenyl-2-picryl hydrazyl (DPPH')}

The DPPH radical scavenging activity of $C$. pedata var. glabra was tested by standard method of Blois [22]. Different sample extracts at various concentrations $(5-250 \mu \mathrm{g})$ were added to $5 \mathrm{ml}$ of a $0.1 \mathrm{mM}$ methanolic solution of $\mathrm{DPPH}^{\cdot}$ and allowed to stand for $20 \mathrm{~min}$ at $27^{\circ} \mathrm{C}$. The absorbance of the sample was measured at $517 \mathrm{~nm}$. Radical scavenging activity was expressed as the inhibition percentage of free radical by the sample and was calculated using the formula: DPPH radical scavenging activity $\%=($ control OD - sample OD/control OD $) \times 100$.

\section{Antioxidant activity by radical cation 2, 2- diphenyl-1-picryl- hydrazyl $\left(\mathrm{ABTS}^{++}\right)$}

The $\mathrm{ABTS}^{++}$radical scavenging activity of the plant extracts was measured by the standard method of Re et al. [23], ABTS ${ }^{\circ+}$ was produced by reacting $7 \mathrm{mM}$ ABTS aqueous solution with $2.4 \mathrm{mM}$ potassium persulfate in the dark for $12-16 \mathrm{~h}$ at room temperature. Before assay, this solution was diluted in ethanol and equilibrated at $30^{\circ} \mathrm{C}$ to give an absorbance at $734 \mathrm{~nm}$ of $0.700 \pm 0.02$. The stock solution of the sample extracts was diluted such that after the introduction of $10 \mu \mathrm{l}$ aliquots into the assay, they produced between 20 and $80 \%$ inhibitions of the blank absorbance. After the addition of $1 \mathrm{ml}$ of diluted ABTS ${ }^{\circ+}$ solution to $10 \mu \mathrm{L}$ of the sample or Trolox standards (final concentration $0-15 \mu \mathrm{M}$ ) in ethanol, absorbance was measured at $30^{\circ} \mathrm{C}$ exactly $30 \mathrm{~min}$ after the initial mixing. Triplicate determinations were made at each dilution of the standard, and the percentage inhibition was calculated of the blank absorbance at $734 \mathrm{~nm}$ and then was plotted as a function of Trolox concentration. The unit of total antioxidant activity (TAA) is defined as the concentration of Trolox having equivalent antioxidant activity expressed as $\mu \mathrm{mol} / \mathrm{g}$ sample extracts on dry matter.

\section{Metal chelating capacity}

The metal chelating capacity of the plant extracts was measured by the standard method of Yamaguchi et al. [24], the reaction mixture contained $0.25 \mathrm{ml}$ of extracts having the concentration of $250 \mu \mathrm{g}$, $0.25 \mathrm{ml}$ of $1 \mathrm{mM} \mathrm{FeSO} 4$ solution, $1 \mathrm{ml}$ of $0.2 \mathrm{M}$ Tris- $\mathrm{HCl}$ buffer ( $\mathrm{pH}$ 7.4), $1 \mathrm{ml}$ of 2,2' bipyridyl solution, $0.4 \mathrm{ml}$ of $10 \%$ hydroxylamine - $\mathrm{HCl}$ and $2.5 \mathrm{ml}$ of ethanol. The final volume was made up to $5 \mathrm{ml}$ with deionized water and the absorbance was determined at $522 \mathrm{~nm}$. The results were expressed as mg ethylenediaminetetraacetic acid (EDTA) equivalent/g sample extracts.

\section{Antiulcer activity}

Animals

After approval of the Institutional Ethics committee, pathogen-free Wistar strain Albino rats mass ranging from 150 to $200 \mathrm{~g}$ of male breed were used for antioxidant and indomethacin-induced ulcer model. The rats were procured from the Small Animals Breeding Station, Mannuthy, Kerala, India. All in vivo experiments were carried out as suggested by the Institutional Ethical Committee (CPCSEA) (Reg. No. 722/02/a/CPCSEA). The animals were housed in polypropylene cages $(38 \times 23 \times 10 \mathrm{~cm})$ with not more than six animals per cage and maintained under standard environmental conditions (14 h dark/ $10 \mathrm{~h}$ light cycles; temp $25 \pm 2^{\circ} \mathrm{C} ; 35-60 \%$ humidity, air ventilation) and were fed with standard pellet diet (M/s. Hindustan Lever Ltd., Mumbai, India) and fresh water ad libitum. The rats were acclimatized to the environment for 2 weeks before experiment use. Animals were fasted overnight before the experimental schedule, but have free access for water ad libitum.

\section{Sample preparation}

Coarse powder from the shade-dried aerial plant parts of $C$. pedata var. glabra (500 g) was exhaustively extracted using Soxhlet apparatus with absolute ethanol $\left(78.5^{\circ} \mathrm{C}\right)$. The extract was dried (free of solvent) using a vacuum evaporator for condensation. The extract thus obtained was stored in refrigerator and used for antiulcer activity. The residual extract was dissolved in distilled water at the time of study period.

\section{Indomethacin-induced gastric mucosal damage}

Six groups $(n=6)$ of six animals each (male Wistar rats) were fasted overnight before the start of the experiment but have free access for water ad libitum. The first and the second groups received distilled water $(10 \mathrm{ml} / \mathrm{kg}$ per day p.o.), while the third group was treated with omeprazole $\left(10 \mathrm{mg} / \mathrm{kg}\right.$ per day p.o.) whereas $4^{\text {th }}, 5^{\text {th }}$, and $6^{\text {th }}$ groups were administered with the ethanol extract of $C$. pedata var. glabra $(100,200$, and $400 \mathrm{mg} / \mathrm{kg} /$ day p.o.), respectively. On the day 3, indomethacin $(30 \mathrm{mg} / \mathrm{kg}$ ) suspended in $0.5 \%$ carboxymethyl cellulose was given as a single oral dose to the groups 2-6 to induce gastric ulcers, after $30 \mathrm{~min}$ of omeprazole and C. pedata var. glabra extracts treatment. After $5 \mathrm{~h}$ the animals were sacrificed with the overdose of diethyl ether, and the number of ulcer spots in the glandular portion of the stomach was examined macroscopically and measured on square-millimeter paper in each stomach, and the ulcer index (UI) was calculated by adding the total number of ulcer per stomach [25].

\section{Experimental design}

Group I : Untreated control rats.

Group II : Indomethacin (30 mg/kg p.o.) treated rats.

Group III : Standarddrug Omeprazole (10 mg/kgp.o./day)+Indomethacin (30 mg/kg p.o.) treated rats.

Group IV : Pretreated ulcer: C. pedata var. glabra extract $(100 \mathrm{mg} / \mathrm{kg}$ p.o./day+ Indomethacin $(30 \mathrm{mg} / \mathrm{kg}$ p.o.) treated rats.

Group V : Pretreated ulcer: C. pedata var. glabra extract $(200 \mathrm{mg} / \mathrm{kg}$ p.o./day)+Indomethacin (30 $\mathrm{mg} / \mathrm{kg}$ p.o) treated rats.

Group VI : Pretreated ulcer: C. pedata var. glabra extract $(400 \mathrm{mg} / \mathrm{kg}$ p.o./day)+Indomethacin (30 mg/kg p.o.) treated rats.

\section{Measurement of UI}

The stomachs were excised and were examined for hemorrhagic lesions in glandular mucosa. Immediately after the animals were sacrificed, 
their stomachs were dissected out, cut along the greater curvature and the mucosa was rinsed with cold normal saline to remove blood contaminant if any. The sum of the length ( $\mathrm{mm}$ ) of all lesions for each stomach was used as the UI, and the percentage of inhibition (\% I) was calculated as described by Djahanguiri [25] using the following formula:

$$
\% \mathrm{I}=\frac{(\mathrm{USc}-\mathrm{USt})}{\mathrm{USc}} \times 100
$$

Where USc: Ulcer surface area in control and USt: Ulcer surface area in treated animals.

\section{Biochemical estimations}

Determination of gastric volume

After sacrificing the rat, the stomach portion was removed. The gastric contents were transferred into the centrifuge tube and centrifuged at $1000 \mathrm{rpm}$ for $10 \mathrm{~min}$. The supernatant liquid was then transferred to a measuring cylinder, and the volume was measured.

Determination of $\mathrm{pH}$ of gastric content

About $1 \mathrm{ml}$ of the gastric juice was collected, and $\mathrm{pH}$ was directly measured using $\mathrm{pH}$ strip [26]

\section{Determination of free acidity and total acidity}

The total volume of gastric content was measured. The gastric contents were centrifuged and filtered. $1 \mathrm{ml}$ of the gastric juice was pipetted out, and the solution was titrated against $0.1 \mathrm{~N}$ sodium hydroxide using 2-3 drops of Topfer's reagent as an indicator, to the endpoint when the solution turned to yellowish orange color was observed. This indicated the volume of $\mathrm{NaOH}$ required neutralizing the free hydrochloric acid present in the gastric juice. Then, 2-3 drops of phenolphthalein solution were added, and titration was continued until a definite red tinge reappears. The difference between the two readings indicated the volume of $\mathrm{NaOH}$ required neutralizing the combined acid present in the gastric juice. The sum of the two titrations was the total acid present in the gastric juice [27]

Acidity was calculated using formula;

$$
\text { Activity }=\frac{\text { Volume of } \mathrm{NaOH} \times \text { Normality of } \mathrm{NaOH}}{\text { Volumeofgastricjuiceused }} \mathrm{m} . \text { Eq./dl }
$$

\section{Estimation of total proteins}

\section{Reagents}

Alkaline copper reagent:

Solution A: $2 \%$ sodium carbonate in $0.1 \mathrm{~N}$ sodium hydroxide,

Solution B: $0.5 \%$ copper sulfate in $1 \%$ sodium potassium tartrate. $50 \mathrm{ml}$ of solution A was mixed with $1 \mathrm{ml}$ of solution B just before use. Folin's phenol reagent. One volume of folin's reagent was diluted with two volumes of distilled water just before use. Standard $20 \mathrm{mg}$ of bovine serum albumin was dissolved in $100 \mathrm{ml}$ of distilled water. Few drops of $\mathrm{NaOH}$ was added to it aid complete dissolution of bovine serum albumin and to avoid frothing; it was allowed to stand overnight in a refrigerator.

\section{Procedure}

The dissolved proteins in gastric juice were estimated in the alcoholic precipitate obtained by adding $90 \%$ of alcohol with gastric juice in 9:1 ratio, respectively. Then, $0.1 \mathrm{ml}$ of alcoholic precipitate of gastric juice was dissolved in $1 \mathrm{ml}$ of $0.1 \mathrm{~N} \mathrm{NaOH}$ and from this $0.05 \mathrm{ml}$ was taken in another test tube. To this $4 \mathrm{ml}$ of alkaline copper reagent was added and kept for $10 \mathrm{~min}$. Then, $0.5 \mathrm{ml}$ of phenol reagent was added and again 10 min was allowed for color development. Reading was taken against blank prepared with distilled water at $640 \mathrm{~nm}$. The protein content was calculated from a standard curve prepared with bovine serum albumin and has been expressed in terms of $\mu \mathrm{g} / \mathrm{ml}$ of gastric juice [28].

\section{RESULTS AND DISCUSSION}

\section{Quantitative phytochemical evaluation}

As antioxidants, polyphenols protect cell constituents against oxidative damage and limit the risk of various degenerative diseases associated with oxidative stress, by acting directly on ROS or by stimulating endogenous defense system [29]. Total phenolics and tannin content of different solvent extracts of $C$. pedata var. glabra were studied and expressed as tannic acid equivalent. As shown in Table 1 , the total phenolic content was maximum in ethanolic extract $(131.7 \pm 3.6 \mathrm{mg} / \mathrm{g})$ followed by acetone extract $(56.8 \pm 0.8 \mathrm{mg} / \mathrm{g})$. The minimum was recorded in water extract $(54.1 \pm 1.8 \mathrm{mg} / \mathrm{g})$. When compared with other solvent extracts, methanol extract registered higher levels of tannin content $(52.8 \pm 12.9 \mathrm{mg} / \mathrm{g})$ followed by acetone extract $(24.1 \pm 4.5 \mathrm{mg} / \mathrm{g})$. Total flavonoid content was studied and expressed as rutin equivalent. The total flavonoid content was maximum in ethanolic extract $(72.1 \pm 0.9 \mathrm{mg} / \mathrm{g})$ followed by water extracts $(13.8 \pm 0.2 \mathrm{mg} / \mathrm{g})$. Based on these results ethanolic extract of $C$. pedata var. glabra was selected for antioxidant and antiulcer studies. This is in agreement with the reports of Hertog et al. [30] and Yen and Chen [31] who reported that ethanol is an effective solvent for extraction of antioxidants.

\section{In vitro antioxidant activity}

ROS and free radicals are produced as a result of many biochemical and biotransformation reactions undergoing in the body. The ill effects of ROS are nullified by the constitutional or endogenous antioxidant system within the body. However, excessive production of the free radicals and ROS lead to oxidative stress, which plays a role in the pathogenesis of several diseases [32]. The antioxidant properties, as well as the abilities of many herbs and plant-based products to scavenge free radicals, have already been studied.

\section{Reducing power assay}

Antioxidants can be referred to as reductants which inactivate oxidants. They are involved in redox reactions in which one reaction species (oxidant) is reduced at the expense of the oxidation of the antioxidant (reductant). Siddhuraju et al. [21] have reported that the reducing power of bioactive compounds was associated with antioxidant activity. The reducing power of different solvent extracts of $C$. pedata var. glabra aerial plant powder at $20-100 \mu \mathrm{g} / \mathrm{ml}$ concentrations, which may serve as a significant reflection of the antioxidant activity was evaluated using potassium ferricyanide reduction method which is shown in Fig. 1. All the extracts exhibited some degree of reducing power. Increasing absorbance values indicate increasing trend in reducing power. Among the different extracts, ethanol extract exhibited the maximum reductive capability followed by water and acetone extracts. However, their reducing power was inferior to quercetin and tannic acid standards.

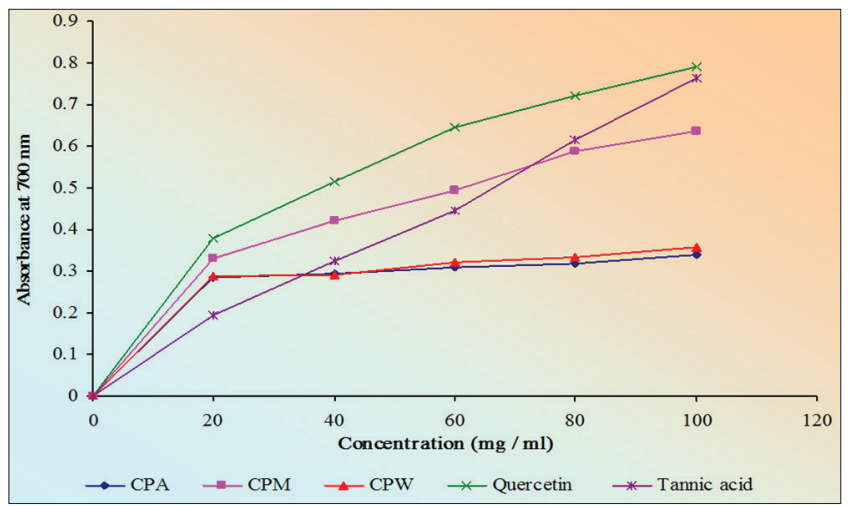

Fig. 1: Reducing ability of different solvent extracts of Cayratia pedata var. glabra. Values are means of triplicate determinations \pm standard deviation. CPA: Acetone extract of C. pedata var. glabra, CPE: Ethanolic extract of $C$. pedata var. glabra, CPW: Water extract of $C$. pedata var. glabra 
Table 1: Estimation of total phenolics, tannin and total flavonoid content of different solvent extracts of $C$. pedata var. glabra aerial plant powder

\begin{tabular}{llll}
\hline Extraction medium & Total phenolics (mg TAE/g extract) ${ }^{\#}$ & Tannin (mg TAE/g extract) $^{\#}$ & Total flavonoid (mg RE/g extract) $^{*}$ \\
\hline Acetone & $56.8 \pm 0.8$ & $24.1 \pm 4.5$ & $13.5 \pm 1.0$ \\
Ethanol & $131.7 \pm 3.6$ & $52.8 \pm 12.9$ & $72.1 \pm 0.9$ \\
Water & $54.1 \pm 1.8$ & $10.5 \pm 3.2$ & $13.8 \pm 0.2$ \\
\hline
\end{tabular}

\#Values are means of three independent analysis \pm standard deviation. TAE: Tannic acid equivalent, RE: Rutin equivalent, C. pedata: Cayratia pedata

\section{DPPH scavenging activity}

The DPPH is a stable organic free radical which has been extensively used for evaluating the free radical scavenging potential of natural antioxidants [33]. As shown in Fig. 2, at 5-250 $\mu \mathrm{g} / \mathrm{ml}$ concentrations, the $\mathrm{IC}_{50}$ values of the plant extracts (acetone, ethanol, and water) and standards (Quercetin and Tannic acid) on DPPH radical scavenging activity were $10.01 \pm 1.08 \mu \mathrm{g} / \mathrm{ml}, 32.13 \pm 2.37 \mu \mathrm{g} / \mathrm{ml}, 185.87 \pm 1.04 \mu \mathrm{g} /$ $\mathrm{ml}, 0.72 \pm 0.29 \mu \mathrm{g} / \mathrm{ml}$, and $1.02 \pm 0.3 \mu \mathrm{g} / \mathrm{ml}$, respectively. The highest $\mathrm{DPPH}$ radical scavenging potential as indicated by the lowest $\mathrm{IC}_{50}$ concentration was recorded for the acetone extract $\left(\mathrm{IC}_{50} 10.01 \pm 1.08 \mu \mathrm{g} /\right.$ $\mathrm{ml}$ ) followed by ethanol extract $\left(\mathrm{IC}_{50} 32.13 \pm 2.37 \mu \mathrm{g} / \mathrm{ml}\right)$. The reaction of reducing the stable radical DPPH to the yellow colored diphenylpicrylhydrazine, indicating that these extracts are active in DPPH radical scavenging. This sample compares well with the quercetin standard $\left(\mathrm{IC}_{50} 0.72 \pm 0.20 \mu \mathrm{g} / \mathrm{ml}\right)$. Siddhuraju et al. [21] reported that a high concentration of tannins (proanthocyanidins) extracted from the stem bark of Cassia fistula exhibited elevated $\mathrm{DPPH}^{\bullet}$ radical quenching capacity.

\section{$\mathrm{ABTS}^{*+}$ scavenging activity}

$\mathrm{ABTS}^{\circ+}$ assay is an excellent tool for determining the antioxidant activity of hydrogen - donating antioxidants (Scavenging aqueous phase radicals) and of chain-breaking antioxidants (Scavenging lipid peroxyl radicals)[34]. The ABTS radical cation scavenging activity of different solvent extracts of $C$. pedata var. glabra plant powder is represented in Table 2. The activity of the tested sample extracts was expressed as Trolox equivalent - the micromolar Trolox solution having an antioxidant capacity equivalent to $1 \mathrm{~g}$ dry matter of the substance under investigation. In this assay, TAA reflects the ability of hydrogen donating antioxidants to scavenge the ABTS radical cation, as compared with that of Trolox. All the samples exhibited $\mathrm{ABTS}^{*+}$ scavenging activity; the water extract exhibited strong TAA $(4628.5 \pm 208.6 \mu$ $\mathrm{mol} / \mathrm{g}$ ) followed by acetone and ethanol extract with TAA values of $4387.5 \pm 169.5 \mu \mathrm{mol} /$ gand $1803.2 \pm 220.95 \mu \mathrm{mol} / \mathrm{g}$,respectively. Kumar et al. [35] evaluated the total antioxidant potential of commonly used medicinal plants and concluded that phenolic compounds of plants play a key role in scavenging of $\mathrm{ABTS}^{\bullet+}$ free radicals.

\section{Metal ion chelating capacity}

The transition metal ion is capable of generating free radicals from peroxides by Fenton reactions [36]. An important mechanism of antioxidant activity is the ability to chelate/deactivate transition metals. The chelating effects of the sample extracts are shown in Table 2. The final reaction mixture contains $1 \mathrm{mg}$ of all samples, and the values are expressed as mg EDTA/g extract equivalent. All the extracts demonstrated the ability to chelate ions. Among the samples tested, ethanol extract (1016.3 $\pm 7.6 \mathrm{mg}$ EDTA/g sample) showed a higher value. Acetone extract showed the minimum value of $873.3 \pm 0.1 \mathrm{mg}$ EDTA/g sample. In similar lines, Elmastas [37] reported that alcohol extract of Juniperus communis fruit showed stronger chelation of ferrous ions.

\section{Antiulcer activity}

\section{Indomethacin-induced ulcer model}

Gastric lesions developed due to loss of the delicate balance between gastroprotective and aggressive factors. Reduction in gastroprotective factors results in gastric ulceration [38]. The use of omeprazole in the study was due to its increasing prescription in ulcer patients in this country specifically due to its non antisecretory
Table 2: $\mathrm{ABTS}^{\bullet+}$ scavenging and metal chelating activity of different solvent extracts of $C$. pedata var. glabra

\begin{tabular}{lll}
\hline Sample & $\begin{array}{l}\text { TAA* }(\mu \text { M trolox } \\
\text { equivalent/g } \\
\text { extract) }\end{array}$ & $\begin{array}{l}\text { Metal chelating activity** }(\mathbf{m g} \\
\text { EDTA equivalent/g sample })^{*}\end{array}$ \\
\hline Acetone & $4387.5 \pm 169.5$ & $873.3 \pm 0.1$ \\
Ethanol & $1803.2 \pm 220.9$ & $1016.3 \pm 7.6$ \\
Water & $4628.5 \pm 208.6$ & $935.3 \pm 11.1$ \\
\hline
\end{tabular}

"Values are means of triplicate determinations \pm standard deviation. *TAA ( $\mu$ mol equivalent Trolox performed using $\mathrm{ABTS}^{\bullet+}$ ). ${ }^{* *}$ Metal chelating activity (mg ethylene diamine tetraacetic acid equivalent/g sample) ${ }^{\#}$. C. pedata: Cayratia pedata. TAE: Tannic acid equivalent, EDTA: Ethylenediaminetetraacetic acid, ABTS: 2, 2- diphenyl-1-picryl-hydrazyl

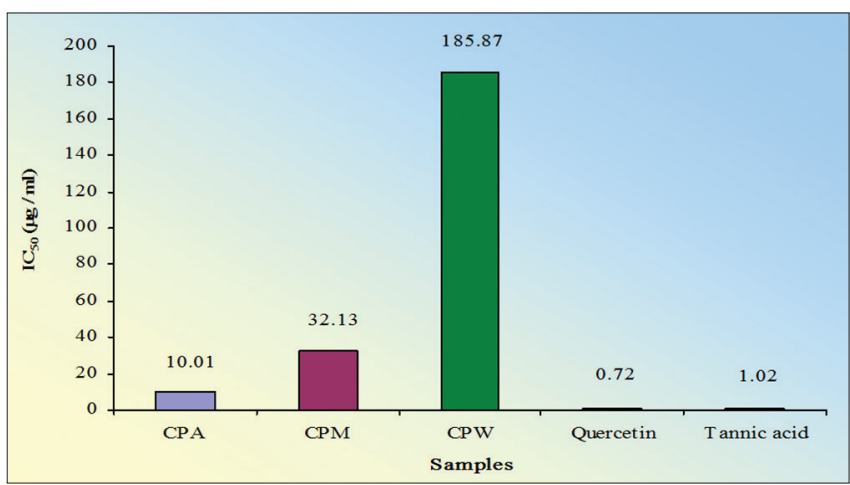

Fig. 2: 1,1-diphenyl-2-picryl hydrazyl scavenging activity of different solvent extracts of Cayratia pedata var. glabra. Values are means of triplicate determinations \pm standard deviation. CPA: Acetone extract of $C$. pedata var. glabra, CPE: Ethanolic extract of $C$. pedata var. glabra, CPW: Water extract of $C$. pedata var. glabra

but mucoprotective nature. Indomethacin IN is one of the most widely used NSAIDs; it damages gastrointestinal mucosa by irritant action, causing alterations in mucosal permeability and suppression of prostaglandin synthesis [39]. In Table 3, the oral administration of indomethacin $(30 \mathrm{mg} / \mathrm{kg}$ body weight $[\mathrm{bw}])$ caused a significant $(p<0.05)$ increase in the number of lesions in the gastric mucosa. The extracts of $C$. pedata var. glabra exhibited concentrationdependent and marked gastroprotection and neutralization in indomethacin-induced ulcer model at the doses of 100, 200, and $400 \mathrm{mg} / \mathrm{kg}$ bw (Plate 1). The sample at $400 \mathrm{mg} / \mathrm{kg}$ bw showed a significant decrease in the UI $(77.10 \%)$ in close proximity with omeprazole (79.92\%) used at a dose level of $10 \mathrm{mg} / \mathrm{kg}$ bw. Ulcer inhibition was highest with $400 \mathrm{mg} / \mathrm{kg}(77.10 \%)$ and recorded the lowest with $100 \mathrm{mg} / \mathrm{kg}$ (73.26\%). In the present study, the plant extract produces a cytoprotection similar to those of omeprazole in the indomethacin model.

The level of gastric volume, free acidity, and total acidity and protein content was increased in the Group-II (indomethacin treated) when compared to standard drug omeprazole and plant extracts at different concentrations $(100 \mathrm{mg} / \mathrm{kg}, 200 \mathrm{mg} / \mathrm{kg}$, and $400 \mathrm{mg} / \mathrm{kg})$. C. pedata var. glabra ethanolic extraction in $400 \mathrm{mg} / \mathrm{kg}$ treated group shown a 
Table 3: Effect of ethanolic extract of $C$. pedata var. glabra against indomethacin-induced gastric ulcer in Wistar albino rats

\begin{tabular}{|c|c|c|c|}
\hline Treatment & Dose (mg/kg bw) & UI & Protection (\%) \\
\hline Control & - & - & - \\
\hline Indomethacin & 30 mg/kg p.o. & $51.8 \pm 8.04^{\mathrm{a}}$ & - \\
\hline Omeprazole+IN & $10 \mathrm{mg} / \mathrm{kg}+30 \mathrm{mg} / \mathrm{kg}$ & $10.4 \pm 1.94^{\mathrm{d}}$ & 79.92 \\
\hline $\mathrm{CPE}+\mathrm{IN}$ & $100 \mathrm{mg} / \mathrm{kg}+30 \mathrm{mg} / \mathrm{kg}$ & $29.1 \pm 2.1^{\mathrm{b}}$ & 43.72 \\
\hline $\mathrm{CPE}+\mathrm{IN}$ & $200 \mathrm{mg} / \mathrm{kg}+30 \mathrm{mg} / \mathrm{kg}$ & $19.1 \pm 1.9^{c}$ & 62.97 \\
\hline $\mathrm{CPE}+\mathrm{IN}$ & $400 \mathrm{mg} / \mathrm{kg}+30 \mathrm{mg} / \mathrm{kg}$ & $11.8 \pm 0.6^{\mathrm{d}}$ & 77.10 \\
\hline
\end{tabular}

\#Values are means of independent analysis \pm standard deviation ( $\mathrm{n}=5$ ), Mean values within a column with no common superscript differ significantly

$(\mathrm{p}<0.05)$, CPE: Ethanolic extract of C. pedata var. glabra, IN: Indomethacin, C. pedata: Cayratia pedata, bw: body weight

Table 4: Effect of ethanolic extract of $C$. pedata var. glabra against indomethacin-induced gastric ulcer in Wistar albino rats - Biochemical parameters

\begin{tabular}{|c|c|c|c|c|c|c|}
\hline Treatment & Dose (mg/kg bw) & $\begin{array}{l}\text { Gastric volume } \\
\text { (ml/100g) }\end{array}$ & pH & $\begin{array}{l}\text { Free acidity } \\
(\mathrm{mEq} / \mathrm{dl})\end{array}$ & $\begin{array}{l}\text { Total acidity } \\
(\mathrm{mEq} / \mathrm{dl})\end{array}$ & $\begin{array}{l}\text { Total protein } \\
(\mu \mathrm{g} / \mathrm{ml})\end{array}$ \\
\hline Control & - & $2.366 \pm 0.14$ & $1.25 \pm 0.10$ & $3.458 \pm 0.39$ & $4.506 \pm 0.02$ & $210.80 \pm 7.01$ \\
\hline Indomethacin & 30 mg/kg p.o. & $7.031 \pm 0.27$ & $2.14 \pm 0.11$ & $6.617 \pm 0.22$ & $7.359 \pm 0.21$ & $395.11 \pm 5.45$ \\
\hline Omeprazole+IN & $10 \mathrm{mg} / \mathrm{kg}+30 \mathrm{mg} / \mathrm{kg}$ & $3.720 \pm 0.16$ & $3.11 \pm 0.14$ & $3.068 \pm 0.12$ & $4.040 \pm 0.13$ & $255.46 \pm 5.74$ \\
\hline CPE+IN & $100 \mathrm{mg} / \mathrm{kg}+30 \mathrm{mg} / \mathrm{kg}$ & $6.336 \pm 0.20$ & $2.43 \pm 0.12$ & $6.598 \pm 0.11$ & $7.028 \pm 0.35$ & $385.64 \pm 5.89$ \\
\hline $\mathrm{CPE}+\mathrm{IN}$ & $200 \mathrm{mg} / \mathrm{kg}+30 \mathrm{mg} / \mathrm{kg}$ & $5.821 \pm 0.15$ & $2.18 \pm 0.16$ & $5.594 \pm 0.18$ & $6.695 \pm 0.37$ & $324.42 \pm 4.89$ \\
\hline $\mathrm{CPE}+\mathrm{IN}$ & $400 \mathrm{mg} / \mathrm{kg}+30 \mathrm{mg} / \mathrm{kg}$ & $4.645 \pm 0.12$ & $2.54 \pm 0.47$ & $3.105 \pm 0.28$ & $5.45 \pm 0.20$ & $316.21 \pm 7.45$ \\
\hline
\end{tabular}

"Values are means of independent analysis \pm standard deviation ( $\mathrm{n}=5$ ), CPE: Ethanolic extract of C. pedata var. glabra; IN: Indomethacin, C. pedata: Cayratia pedata

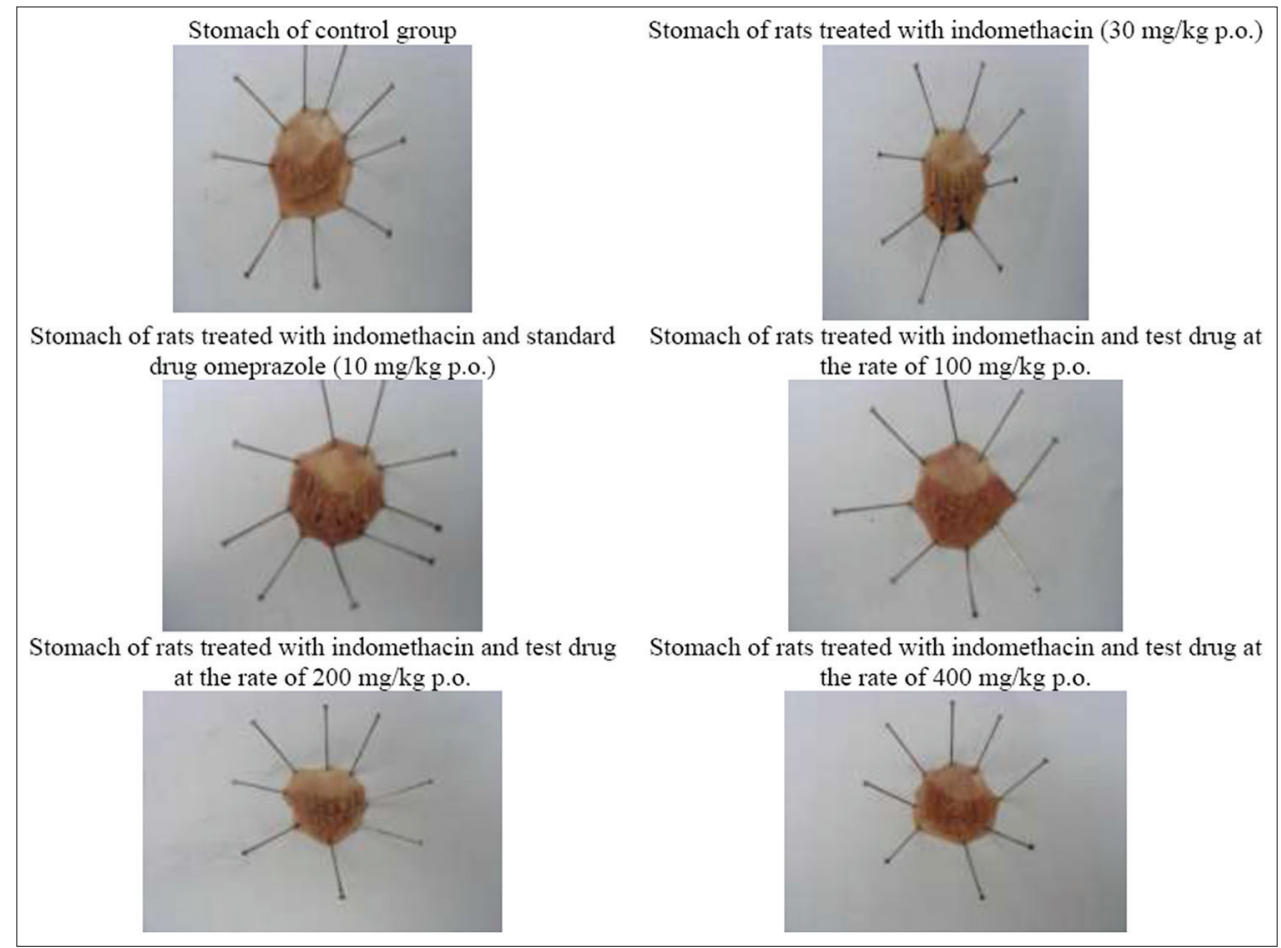

Plate 1: Effect of ethanolic extract of Cayratia pedata var. glabra against indomethacin-induced gastric ulcer in Wistar albino rats

decrease in the level of free acidity which is more or less equal to that of standard omeprazole. Decreased level of gastric volume was observed in $400 \mathrm{mg} / \mathrm{kg}$ plant extract treated group. The level of $\mathrm{pH}$ was decreased in the Group-II (indomethacin treated) when compared to the standard drug omeprazole and plant extracts at different concentrations (100 mg/kg, $200 \mathrm{mg} / \mathrm{kg}$, and $400 \mathrm{mg} / \mathrm{kg}$ ) (Table 4). In similar lines, phytosterols which have been shown various properties that are necessary for protection against ulcer induction. Since flavonoids and sterols shown to be present in the chloroform extract of Cayratia pedata Lam. these constituents may be responsible for the antiulcer activity [40]. The natural resin obtained from Shorea robusta Gaertn. F. is a reputed folklore remedy in its natural form for the treatment of ulcer, inflammation, and wounds. Pretreatment with the resin SRR produced $62.69 \%$ inhibition of gastric mucosal damage in ethanol-induced model and $64.55 \%$ inhibition in PL-induced model which was comparable to the reference drug omeprazole [41]. In same line, Ficus religiosa has been investigated for the presence of a wide range of phytoconstituents which impart a wide spectrum of pharmacological activities [42].

\section{CONCLUSION}

In this study, the antioxidant and free radical scavenging activities of different extracts of $C$. pedata var. glabra were evaluated using various 
in vitro methods. The result of the study points indicates that the ethanol extract of $C$. pedata var. glabra contains maximum phytochemical agents with antioxidant and free radical scavenging properties. The results of estimation of total phenolic and total flavonoid content point to the fact that the antioxidant and scavenging activities may be attributed to the presence of these secondary metabolites. On the basis of the results of this study, it clearly indicates that C. pedata var. glabra had powerful in vitro antioxidant capacity against various antioxidant systems as DPPH', reducing power, $\mathrm{ABTS}^{+*}$, and metal chelator. From our results obtained, it can be concluded that this plant extract has a potential to be used as an antiulcer drug in combination with other drugs or alone. Although the mechanism of the antiulcer action of the plant extract remains to be studied in detail. To use the aerial parts of $C$. pedata var. glabra for its potential antioxidant and antiulcer activity, further studies such as isolation, identification, chemical characterization, and in vivo studies of these compounds may be carried in future.

\section{REFERENCES}

1. Thomas CE, Kalayanaraman B. In: Oxygen Radicals and the Disease Process. Netherlands: Harwood Academic Publishers; 1997.

2. Payne CM, Bernstein C, Bernstein H, Gerner EW, Garewal H. Reactive nitrogen species in colon carcinogenesis. Antioxid Redox Signal 1999;1:449-67.

3. Saha MR, Alam MA, Akter R, Jahangir R. In-vitro free radical scavenging activity of Ixora coccinea L. Bangladesh J Pharmacol 2008:3:90-6

4. Yuan X, Gao M, Xiao H, Tan C, Dua Y. Free radical scavenging activities and bioactive substances of Jerusalemartichoke (Helianthus tuberosus (L.) leaves. Food Chem 2012;133:10-4

5. Youwei Z, Jinlian Z, Yonghong P. A comparative study on the free radical scavenging activities of some fresh flowers in southern China. LWT Food Sci Technol 2008;41:1586-91.

6. Rao AV, Agarwal S. Role of antioxidant lycopene in cancer and heart disease. J Am Coll Nutr 2000;19:563-9.

7. Cuzzocrea S, Riley DP, Caputi AP, Salvemini D. Antioxidant therapy: A new pharmacological approach in shock, inflammation, and ischemia/ reperfusion injury. Pharmacol Rev 2001;53:135-59.

8. Bursal E, Köksal E. Evaluation of reducing power and radical scavenging activities of water and ethanol extracts from sumac (Rhus coriaria L.). Food Res Int 2011:44:2217-21.

9. Suja KP, Jayalakshmy A, Arumugham C. In vitro studies on antioxidant activity of lignans isolated from sesame cake extract. J Sci Food Agric 2005;85:1779-83.

10. Dolai N, Karmakar I, Kumar RB, Kar B, Bala A, Haldar PK. Free radical scavenging activity of Castanopsis indica in mediating hepatoprotective activity of carbon tetrachloride intoxicated rats. Asian Pac J Trop Biomed 2012;2:S243-51.

11. Sheela VS, Selvaumar S, Shanthi G. Antiulcer activity of Cayratia pedata, Enicostemma axillare and Terminalia chebula on ethanol induced Albino Wister rats. Int J Mod Res Rev 2016;4:1129-34.

12. Sharmila S, Kalaichelvi K, Premamalini, P. Ecological status of therapeutically important plants in Thiashola, Manjoor, Western Ghats, Tamil Nadu, India. Eur J Pharm Med Res 2016;3:411-6.

13. Sharmila S, Kalaichelvi K, Abirami P. Ethnopharmacobotanical informations of some herbaceous medicinal plants used by Toda tribes of Thiashola, Manjoor, Nilgiris, Western Ghats, Tamilnadu, India. Int J Pharm Sci Res 2015;6:315-20

14. Sharmila S, Kaliachelvi K. Anatomical characterization on the leaf of Cayratia pedata (Lam.) Gagnep. var. glabra Gamble (Vitaceae)-An endemic climber of Western Ghats, India, Sciexplore Int J Res Sci 2016;3:1-5.

15. Jain SK, Rao RR. Hand Book of Field and Herbarium Methods. New Delhi: Today \& Tomorrow's Printers and Publishers; 1970.

16. Fyson PF. The Flora of the Nilgiri and Pulney Hill Tops. Madras: Superintendent, Government Press; 1915-1920. p. 3.

17. Gamble JS, Fischer CE. Flora of the Presidency of Madras. Calcutta: Botanical Survey of India; 1967. p. 1-3
18. Matthew KM. The Flora of the Tamil Nadu Carnatic. Vol. 3. Tiruchirapalli: The Rapinet Herbarium, St. Joseph's College; 1983. p. 278-9.

19. Siddhuraju P, Becker K. Antioxidant properties of various solvent extracts of total phenolic constituents from three different agroclimatic origins of drumstick tree (Moringa oleifera Lam.) leaves. J Agric Food Chem 2003;51:2144-55.

20. Zhishen J, Mengcheng T, Jianming W. The determination of flavonoid contents in mulberry and their scavenging effects on superoxide radicals. Food Chem 1999;64:555-9.

21. Siddhuraju P, Mohan PS, Becker K. Studies on the antioxidant activity of Indian Laburnum (Cassia fistula L.): A preliminary assessment of crude extracts from stem bark, leaves, flowers and fruit pulp. Food Chem 2002;79:61-7.

22. Blois MS. Antioxidant determinations by the use of a stable free radical. Nature 1958;26:1199-200.

23. Re R, Pellegrini N, Proteggente A, Pannala A, Yang M, Rice-Evans C. Antioxidant activity applying an improved ABTS radical cation decolorization assay. Free Radic Biol Med 1999;26:933-56.

24. Yamaguchi F, Ariga T, Yoshimura Y, Nakazawa H. Antioxidative and anti-glycation activity of garcinol from Garcinia indica fruit rind. J Agric Food Chem 2000;48:180-5

25. Djahanguiri B. The production of acute gastric ulceration by indomethacin in the rat. Scand J Gastroenterol 1969;4:265-7.

26. Arun M, Asha VV. Gastroprotective Effect of Dodonaea viscose on various experimental ulcer models. J Ethnopharmacol 2008;24:1-6

27. Jan AM, Mariod AA, Al-Bayaty F, Abdel-Wahab SI. Antiulcerogenic activity of Gynura procumbens leaf extract against experimentally induced gastric lesions in rats. J Med Plants Res 2010;4:685-91.

28. Lowery OH, Rosenbrough NJ, Farr A, Randall RJ. Protein measurment with folin phenol reagent. J Biol Chem 1993;1:265-75.

29. Scalbert A, Manach C, Morand C, Rémésy C, Jiménez L. Dietary polyphenols and the prevention of diseases. Crit Rev Food Sci Nutr 2005:45:287-306.

30. Hertog MG, Hollman PC, Van de Putle B. Content of potentially anticarcinogenic flavonoids of tea infusions, wines and fruit juices. J Agric Food Chem 1993;41:1242-6.

31. Yen GC, Chen HY. Antioxidant activity of various tea extracts in relation to their antimutgenecity. J Agric Food Chem 1995;47:23-32.

32. Velavan S. Free radicals in health and diseases-A mini review. Pharmacol Online 2011;1:1062-77.

33. Orech R, Asokkumar R, Somasundaram A, Sivashanmugam T, Ravi TK. Xanthin oxidase inhibitory activity-Some Indian medicinal plants. J Ethnopharmacol 2005;106:547-51.

34. Kim DO, Lee KW, Lee HJ, Lee CY. Vitamin C equivalent antioxidant capacity (VCEAC) of phenolic phytochemicals. J Agric Food Chem 2002:50:3713-7.

35. Kumar ST, Shanmugam S, Palvannan T, Kumar VM. Evaluation of antioxidant properties of Elaeocarpus ganitrus Roxb. Leaves. Iran J Pharm Res 2008;7:211-5.

36. Yen WJ, Chang LW, Duh PD. Antioxidant activity of Peanut seed testa and its antioxidative component, ethyl protocatechuate. Lebensm Wiss Technol 2005;38:193-200

37. Elmastas M. A study on the in vivo antioxidant activity of Juniper (Juniperus communis L.) fruit extracts. Anal Lett 2006;39:47-65.

38. Ernst PB, Gold BD. The disease spectrum of Helicobacter pylori: The immunopathogenesis of gastroduodenal ulcer and gastric cancer. Annu Rev Microbiol 2000;54:615-40.

39. Mukherjee M, Bhaskaran N, Srinath R, Shivaprasad HN, Allan JJ, Shekhar D, et al. Anti-ulcer and antioxidant activity of GutGard. Indian J Exp Biol 2010;48:269-74.

40. Karthik P, Amudha P, Srikanth J. Study on phytochemical profile and anti-ulcerogenic effect of Cayratia pedatata Lam in albino wistar rats. Pharmacol Online 2010;2:1017-29.

41. Kumar MS, Anusuya N, Bhuvaneswari P. Antiulcerogenic effect of Resin from Shorea robusta Gaertn. F. on experimentally induced ulcer models. Int J Pharm Pharm Sci 2013;5:269-72.

42. Reddy VT, Kumar SH, Bakshi V. Antiulcer Effect of formulation of Aloe vera \& Liquorice againt aspirin induced peptic ulcer. Int J Appl Pharm Sci Res 2016;1:42-5. 